\title{
RIGHT-TO-FOOD: STRENGTHENING THE LEGAL AND POLITICAL CONCEPTS THROUGH SOFT GOVERNANCE
}

\author{
Petr Blizkovsky ${ }^{1 /}$ \\ General Secretariat of the Council of the European Union
}

\begin{abstract}
Addressing poverty issues in the developing world, and hunger issues in particular, is top of the global list of collective actions. However, in spite of the right-to-food commitments taken by global leaders and the international community, the problems are persisting. This article analyses the concept of "right-to-food" from legal and political points of view and looks at the shortcomings for its implementation. A governance analysis is provided together with recommendations for improvement. The experience of the European Union of economic coordination is utilised for improving intergovernmental cooperation for food security. The Food Security Implementation Procedure is considered as a soft method based on a voluntary participation with an objective to strengthen international coordination, national ownership and effective involvement of the non-public sector.
\end{abstract}

Keywords: food security, benchmarking, management of food availability, Africa

\section{Introduction}

Food is a basic need of people and as such, it is a natural candidate for public policy. Yet there are still questions open across the definition of the concept of need, of supply impact on the broader society, on those supplying food and a need for governance at various levels. Food has been one of the items in the agenda for global governance and collective action for decades. However as the challenges grow, fulfilment of the targets continues to be a challenge: feeding a population rising from 7.2 billion in 2014 up to over 9 billion people by 2050 in a world subjected to climate change, land scarcity and land degradation and erosion of natural base resources (FA0, 2015).

According to the FAO, IFAD and WFP (2013), the number of undernourished people declined at global level from 18.9\% in 1990-1992 to $12 \%$ in 2011-2013. These institutions report that undernourishment is down from more than 1 billion in 1992 to around 805 million in 2014 (an improvement of 21\%). Since 1990, 63 countries have reached the hunger target of the Millennium Development Goal 1 and 255 countries have achieved more stringent world summit targets. The hunger target of the Millennium Development Goal halving the proportion of undernourished people in developing countries by 2015 is within reach. Latin America and the Caribbean have made the greatest overall progress in increasing food security with sub-Saharan Africa and western Asia making the most limited progress but this is also due to disasters and conflicts (Committee on World Food Security, 2014). However, there is still 1 in every 9 people suffering from hunger; 161 million children suffer from chronic malnutrition and 99 million from underweight. Most of the world's undernourished people are located in southern Asia (276 million), in sub-Saharan Africa (214 million), eastern Asia (276 million) and Latin America and the Caribbean (37 million). Food security more often affects the people living from primary agriculture production. Some $75 \%$ of the poor people in the world live in rural areas and 2.5 billion farmers, fishermen and foresters are the most vulnerable ones to crisis and disease.

Nevertheless, the problems persist. Page, H. (2013) refers to the fact that whilst global economic assistance generates a global food surplus, the number of hungry and food-insecure people increased. Food security is also facing future challenges of population growth, climate change and need for non-food production. The same author expects that inequalities between regions and between and within countries will grow. Food security will increasingly become an urban problem.

There is a large body of literature studying the right-to-food and food safety from the political point of view, such as Ziegler, Golay, Mahon and Way (2011); ACORD (2010); McKeon (2011) and Riches and Silvasti (2014).

This article aims at analysing the legal concept, the political commitments and the current global governance structure in relation to the right-to-food. Based on this analysis, it will offer proposals for improving the soft method of governance. The key owner of the right-to-food remains the state. Therefore a soft method of governance used by the European Union (EU) in the policy areas where Member States keep the policy competence could be used in order to take stock of lessons learnt in the $\mathrm{EU}$ and show possible ways forward in the area of right-to-food.

\section{Material and methods}

The data used in the article originates from the publically available sources. For the legal analysis, they come from the UN and its specialised agencies, such as FAO. For the intergovernmental part, they are taken from the website of the body concerned and are indicated in Chapter 3.

Methods used for analysing the legal concept are of qualitative nature. It involves critical comparison, mainly of the:
a) legal basis,
b) enforceability,
c) level of implementation.

Concerning the part linked to policy recommendation, the method used is based on the transposition of best practices. To this end a policy governance model used by the European Union in the area of fiscal cooperation - and the imbalance procedure in particular - is transposed on the right-to-food case (as explained in detail in policy recommendation part of the Chapter 3).

\footnotetext{
Petr Blizkovsky is a Director at the General Secretariat of the Council of the European Union. Opinions expressed in the article are purely those of the writer and may not in any circumstances be regarded as stating an official position of the Council of the European Union
} 


\section{Results and discussion}

\section{Analysis of legal concept}

From the legal perspective, the right-to-food, alternatively called the rightto-adequate-food or food security is recognised as being a part of human rights. The concept relates to the right of an individual to be in a situation of a food security. It was analysed amongst others by Mechlem (2004); Courtis (2007); Golay and Özden (2012) and by the Special Rapporteur on the right to food (De Schutter, 2008, 2009, 2010; United Nations General Assembly, 2009; Human Rights Council, 2010). It has undergone its evolution starting from the post-war shortage of food in the post-war period, followed in the 60 's by post-colonialist developments with the expansion of the concept to cover food security and nutrition of individuals (Page, 2013). In the 70's, the concept was broadened and took into account poverty and deprivation in relation to malnutrition. In the $80^{\prime}$ 's, as a response to the food crisis the concept was further enlarged to other specific goals: adequacy and stability of food supply and markets and security of access to supplies.

The right-to-food is a legal concept. The first source of a legal basis for the concept of food security appeared initially after the Second World War. The right-to-food is a part of the Universal Declaration of Human Rights, adopted on 10 December 1948 by the General Assembly of the United Nations. Article 25(1) of that Declaration reads:

"Everyone has the right to a standard of living adequate for the health and well-being of himself and of his family, including food, clothing, housing and medical care and necessary social services, and the right to security in the event of unemployment, sickness, disability, widowhood, old age or other lack of livelihood in circumstances beyond his control."

The concept of right-to-food as being a part of the human rights merits legal analysis. Lanre (2015) provides the following characteristic of the two categories of human rights in relation with placing negative or positive obligations on states: "The first category are the civil and political rights which is called first generation rights. These are "liberty-orientated" and include the rights to life, liberty and security of the individual; freedom from torture and slavery; political participation; freedom of opinion, expression, thought, conscience and religion; freedom of association and assembly. Firstgeneration human rights deal essentially with liberty and participation in political life. They are fundamentally civil and political in nature, as well as strongly individualistic. They serve negatively to protect the individual from the excesses of the state. The second category are the economic and social rights, also called second generation rights. These are "security-orientated" rights, for example the right to work; education; a reasonable standard of living; food; shelter and health care. Eventually a third category of collective rights, a third generation, can be established. It includes the right to live in an environment that is clean and protected from destruction and rights to cultural, political and economic development."

Lanre (2015) offers the following characteristics of the two generations of rights. The first generation of rights was a priority for western democracies during the Cold War; the second generation was a priority for the socialist states. The first generation put negative obligations on states, the second generation of rights place positive obligations on states. The same author notes that at the end of the Cold War, it became generally accepted that such a dichotomy does not do justice to the extent to which these rights are interrelated and interdependent, indivisible and potentially entailing a variety of obligations on the state. These obligations may be categorised as the duty to respect, protect, promote and fulfil. Michael and McDermott (2012) note that the parties participating in the drafting conferences for the Universal Declaration of Human Rights generally agreed that there should be a social and economic right-to-food, but disagreed about imposing a positive obligation on states.

To what extent is the right-to-food, as defined in the UN Declaration, a legally binding and enforceable right? The Universal Declaration of Human Rights should be seen as not legally binding and not even for those countries who voted in its favour and it does not require states to create positive, enforceable laws. This resolution has the character of a recommendation and is not a treaty. Breaching it can only lead to public disapproval but cannot serve as a basis, for example, for a judgment of the International Court of Justice or, even at national level, for the annulment of administrative acts by courts.

The second legal basis for the right-to-food came almost 30 years after the UN Declaration on Human Rights. The right-to-food received relatively little attention until 1976, when the International Covenant on Economic, Social and Cultural Rights (ICESCR) entered into force. Here, Article 11 recognised the right-to-food:

"The States party to the present Covenant recognize the right of everyone to an adequate standard of living for himself and his family, including adequate food, clothing and housing, and to the continuous improvement of living conditions. The States Parties will take appropriate steps to ensure the realization of this right, .... The States Parties to the present Covenant, recognizing the fundamental right of everyone to be free from hunger, shall take, individually and through international co-operation, the measures, including specific programmes, which are needed: To improve methods of production, conservation and distribution of food by making full use of technical and scientific knowledge, by disseminating knowledge of the principles of nutrition and by developing or reforming agrarian systems in such a way as to achieve the most efficient development and utilization of natural resources; Taking into account the problems of both food-importing and food-exporting countries, to ensure an equitable distribution of world food supplies in relation to need."

The legal concept adopted by ICESCR is broader and refers to standards of living, including adequate food. It also called on States party to ICESCR to ensure the realisation of this right. However, similarly to the UN Declaration, such a right is not legally binding and nor is it directly applicable. Later on, the UN Committee on Economic, Social and Cultural Rights adopted, in 1999, General Comment 12, in which the ICESCR's definition of Article11 is interpreted and a notion of a right to adequate food is added. The General Comment notes that the right-to-food should not be understood in a restrictive way linked to the access to a minimum amount of calories, proteins or micronutrients. It reads as follows:

"The right to adequate food is realised when every man, woman and child, alone or in community with others, has physical access at all times to adequate food or means for its procurement. The core content of the right to adequate food implies ...the availability of food in quantity and quality sufficient to satisfy the dietary needs of individuals...".

In addition, an Optional Protocol to the International Covenant on Economic, Social and Cultural Rights entered into force on 5 May 2013. It gives competence to the UN Committee on Economic, Social and Cultural Rights to consider complaints from individuals or groups who claim their rights under the Covenant have been violated. However, that Committee can only denounce the attitude of the state which ratified the Covenant. Since the Committee holds no decision-making power or power of coercion, the implementation of its proposals depends solely on the goodwill of governments

In order to encourage the implementation of the concept of rightto-food into national legal systems, the FAO had adopted the Voluntary Guidelines to Support the Progressive Realisation of the Right to Adequate 
Food in the Context of National Food Security (FA0, 2005). Legally speaking, it is a political declaration which provides states with guidelines on how to incorporate Article 11 in their national legislation.

Therefore, the key element for putting right-to-food into practice is the implementation of the UN Declaration and ICESCR into national legislations. Such implementation is as yet an unfinished task. According to Beuchelt and Virchow (2012), it is currently included into a constitution of 40 states and the right is justiciable or likely to be justiciable in 54 states. This means that the concept of right-to-food can be enforced by courts. Without such implementation into national legal systems, the right-to-food is not enforceable for citizens.

\section{Analysis of political commitments}

In parallel to the legal concept of right-to-food, the global community agreed on the definition of food security and undertook several political commitments to improve its situation.

On the definition side, the World Food Conference (WFC), in 1974, defined food security as:

"... availability at all times of adequate world food supplies of basic foodstuffs to sustain a steady expansion of food consumption and to offset fluctuations in products and prices."

In the 1990, UNICEF dealt with right-to-food from the perspective of the child and made a distinction between food and non-food factors, such as care and health, in relation to the nutrition of children.

Finally, the concept of food security was defined by the Committee on World Food Security (CFS) in 2012 in the following way:

"Food and nutrition security exists when people at all times have physical, social and economic access to food which is safe and consumed in sufficient quantity and quality to meet their dietary needs and food preferences, and is supported by an environment of adequate sanitation, health service and care allowing for a healthy active life."

On the commitment side, several political documents dealing with food security were adopted. The Rome Declaration on World Food Security was adopted in 1996 by the World Food Summit organised by FA0. The document confirms the right of all people to safe and nutritious food as being a part of the fundamental right of everyone to be free from hunger. It calls on states to make the commitment to reach this objective and to reduce the number of undernourished people to half by 2015. Parties also adopted the World Food Summit Plan of Action to implement such a commitment. A follow-up Word Food Summit was organised in 2002 to evaluate the progress made.
In parallel, the FAO and WHO organized the First and Second International Conferences on Nutrition in 1992 and in 2014, to confirm the right-to-food and to adopt goals and targets to improve nutrition globally.

In the $2^{\text {nd }}$ Rome Declaration on Nutrition (Committee on World Food Security, 2014) the Heads of States and Governments:

"... reaffirmed the rights of everyone to have access to safe, sufficient and nutritious food, consistent with the right to adequate food and the fundamental right of everyone to be free from hunger consistent with the International Covenant on Economic, Social and Cultural Rights and other relevant United Nations instruments." They also recognised that"...the progressive realisation of the right to adequate food in the context of national food security is fostered through sustainable, equitable, accessible in all cases and resilient and diverse food systems."

At the same time, the leaders came with ten commitments for action which comprise: eradicating hunger; increasing investments for improving peoples' diets; enhancing a sustainable food system; raising the profile of national strategies; improving collaboration within and across counties including North/South cooperation, South/South cooperation and triangular cooperation. In parallel to the adoption of the Rome Declaration, a framework for action has been agreed (FAO and WHO, 2014b).

The World Summit on Food Security in Rome, in 2009, adopted a declaration committing states to eradicating hunger by the earliest possible date and to increasing aid to agriculture in developing countries. The declaration confirmed the target for reducing hunger by half by 2015 . It also comprises five principles for sustainable global food security. The Millennium Development Goals were adopted in 2000 by all UN Member States and several international organisations. Among the 8 goals agreed to be implemented by 2015 , the first one refers to the eradication of hunger. The target of hunger reduction is close to being reached. At the Rio +20 Conference on Sustainable Development in 2012, the UN Secretary General announced the Zero Hunger Challenge (FA0, 2014a). This is a proposal to the global leaders containing 5 pillars: $100 \%$ access to food and nourishment all year round; ending starvation among children under the age of two years; making all food systems more sustainable; doubling productivity and income for smallholder farmers; reducing food waste and post-harvest losses.

The above analysis demonstrated the complexity of legal and political concept of access to food and food security. Table 1 provides an overview.

As a conclusion to the analysis of the legal and political concepts of the right-to-food, the following can be noted:

Table 1 Evolution of the concept of right-to-food

\begin{tabular}{|c|c|c|c|c|}
\hline Period & Body & Content & Nature & Enforcement \\
\hline 1948 & UN & food access & legal & indirectly, transposition into national legal system needed \\
\hline 1974 & WFC & food access & political & $\mathrm{N} / \mathrm{A}$ \\
\hline 1976 & ICESCR & food access & legal & indirectly, transposition into national legal system needed \\
\hline 1990 & UNICEF & child nutrition & political & N/A \\
\hline 2004 & FAO & voluntary guidelines & political & $\mathrm{N} / \mathrm{A}$ \\
\hline 1992,2014 & Rome Declaration on Nutrition & food access. no hunger, commitments & - & \\
\hline 2012 & CFS & food access specification & political & $\mathrm{N} / \mathrm{A}$ \\
\hline 2012 & World Summit on Food Security & food access. no hunger, commitments & political & N/A \\
\hline 2013 & ICESCR & compliance mechanism & legal & direct with limitation \\
\hline
\end{tabular}


$\square$ Right-to-food is a part of the universal rights of the second generation of human rights.

$\square$ The legal concept of such a right is neither directly binding nor enforceable by international bodies and is mainly of a declaratory nature.

$\square$ The key actor in the implementation of the right-to-food remains an individual state as a sovereign. There is an implementation progress; however a lot remains to be done.

$\square$ Definition of the right-to-food provides the general objectives of the right but lacks quantification, repartition of responsibility between the individual person, municipality, state and international community.

$\square$ There are multiple political commitments on improving food security and access to food for each person. However, the commitments remain general and the responsibility for individual states is unclear.

\section{Governance analysis: implementation of commitments}

In general, governance is defined as formal and informal rules, organisations and processes through which public and private actors articulate their interests and implement decisions (Page, 2013). The World Bank defines governance as: "the manner in which power is exercised in the management of a country's economic and social resources for development". Alternate definitions see governance as "the use of institutions, structures of authority and even collaboration to allocate resources and coordinate or control activity in society or the economy", or the "proper functioning of institutions and their acceptance by the public" (legitimacy). It has also been used to invoke the efficiency of government and the achievement of consensus by democratic means (participation). De Haen and MacMillan, 2010 refer to global governance as the institutional process of bringing about cooperative actors among states and non-state actors at transnational level to resolve problems that affect more than one state or region.

The governance of food security lacks a generally accepted definition. However, it arguably comprises the following components: creating and exchanging food security information; setting standards and actively promoting the knowledge required to achieve food security goals; ensuring cohesion between food security strategies, policies, rules and relations; providing technical assistance and setting up food security projects and programmes across borders; coordinating international assistance during food security emergencies (FA0, 2014c).The global governance on food security means establishment of mechanisms that facilitate debate, convergence of views and coordination of actions to improve food security at global, macroregional and national levels (FA0, 2014c).

The governance structure of food security has evolved. The FAO was originally established as an inter-governmental body to promote the common welfare by furthering collective actions of raising levels of nutrition and standards of living. Governments were major players within the FAO. The Rome Declaration on Nutrition (FAO and WHO, 2014a) appointed FAO and WHO in collaboration with other UN agencies, funds and programmes, as well as other international organisations to develop, strengthen and implement policies, programmes and plans to address malnutrition. The Rome Declaration was suggested for endorsement by United Nations General Assembly. Other stakeholders such as NGO's, CSO's and the private sector were involved progressively. This led to higher participation of multiple actors and more decentralised governance which resulted in a shift from UN-based governance towards a multi-stakeholder system. The governance structure covers international, regional and national levels. Multi-stakeholder platforms and involvement of different actors in society are seen as preconditions for success (FAO and WHO, 2014a).
As of the 70's, the Committee on World Food Security (CFS) evolved as a key actor in the food security governance (FA0, 2014b). It aims at supporting both national efforts and global/macro-regional concerns. It was established in 1974 as an intergovernmental body within the UN structure. Its mission is to review and monitor the national and international food security policies. The CFS undertook a reform in 2009 which resulted in involvement of multi-level stakeholders. The CFS reports to the Economic and Social Council of the United Nations (ECOSOC). The CFS is an open forum which recognises three categories of stakeholder participation at its meetings: the CFS is made up of Members, Participants and Observers. The membership of the Committee is open to all Member States of the FA0, the International Fund for Agricultural Development (IFAD), the World Food Programme (WFP) and non-Member States of FAO but which are Member States of the United Nations. Member States are encouraged to participate in CFS sessions at the highest level possible. Participants are the representatives of UN agencies and bodies, civil society, non-governmental organisations, agricultural research systems, international and regional financial institutions and representatives of private sector associations and private foundations. The CFS may invite other interested organisations, relevant to its work, to observe entire sessions or specific agenda items. As an illustration of the representativeness of the CFS, at its meeting in 0 ctober 2014 participated 111 Member States, 10 non-Member States, 10 United Nations agencies and bodies, 81 civil society organisations, 73 private sector associations and foundations, 2 international research organisations, 1 international financial institution and 42 observers (Committee on World Food Security, 2014).

The CFS preparatory work involves the Right-to-Food Team, Global Forum on Food Security and Nutrition, and the High Level Panel of Experts on Food Security and Nutrition (HLPE).The HLPE was created in 2009 as a part of the CFS reform to provide independent, scientific knowledge-based analysis and advice. HLPE reports are requested by CFS and their findings and recommendations serve as a basis for (FS policy discussions (FA0, 2014b).

The main institutions involved in the food security governance are the FA0, the World Food Programme (WFP) and the International Fund for Agricultural Development (IFAD). The World Health Assembly (WHA) and the FAO conferences provide fora for government discussions over health and agriculture (FAO and WHO, 2014c). The UN General Assembly issues resolutions on food security and nutrition. International and national policies have been involved, bilateral agencies, financial institutions, foundations, equity funds and private companies are actors of food security. Aquila Food Security Initiative (AFSI) launched by the $\mathrm{G} 8$ and the Comprehensive Africa Agriculture Development Programme (CAADP) represent regional initiatives (Page, 2013).

Multi-stakeholder actors, including civil society are involved in the food security effort. An example is Africa Solidarity Trust Fund. It was launched by Equatorial Guinea, Angola and NGO's in the Republic of Congo, in 2013, with a lending capacity of 40 million USD. It aims at the improvement of the agriculture sector and food security in Africa. It finances measures for youth employment, management of natural resources, and resilience of livelihoods and eradication of hunger by sustainable food production. It has launched 6 national projects and 4 macro-regional cross-national projects (FA0, 2014d).

At the global level, each food crisis has typically produced a specific governance initiative. In 2008, it was the High Level Task Force on the global food security crisis (HLTF). It produced the Comprehensive Framework for Actions (CFA) aiming at concerted responses to the food price crisis and the needs of vulnerable populations. The G8 issued, in 2008, the Tokyo Statement 
on Global Food Security defining commitments and measures for ensuring global food security. It recognised the coordinating role of the UN. In 2009, the G8 Summit adopted Aquila Food Security Initiative (AFSI) which together with Aquila Joint Statement on Global Food Security committed to additional agriculture investment of 22 billion USD within 3 years. The World Summit on Food Security, in 2009, adopted 5 principles for sustainable global food security. Global Agriculture and Food Security Programme (GAFSP) is a financing mechanism managed by the World Bank with the aim of achieving the Millennium Goal 1. The Framework for Scaling Up Nutrition (SUN) is a multi-stakeholder movement focussing on improving nutrition and having a 1000 day plan for actions.

In addition, food security appears as an issue for other international organisations such as $\mathrm{OECD}$, the World Economic Forum, the EU and the G8/G20. The G20 adopted, in 2011, the Action Plan on Food Price Volatility and Agriculture and launched the Agriculture Market Information System. The BRIC countries at their meeting in 2010, at the level of Agriculture Ministers, established an action plan for 2012-2016 and adopted the initiative Making Joint Efforts for World Food Security in 2011.

Under the global level of governance of food security there is the regional level. In this respect, the UN Regional Economic Communities (REC's) have been growing in importance. Other existing regional cooperation structures have the right-to-food dimension. These include the African Union (AU), the Economic Community of West African States (ECOWAS), the Intergovernmental Authority on Development (IGAD), the Economic Cooperation Organisation (ECO) and the Caribbean Community (CARICOM) which are also dealing with food security.

Finally, there is the national level which has the central responsibility for the implementation of food security. Eventually this level is the one which can be subject to coercive actions.

The private sector acts individually and collectively in food security together with civil society, NGO's, research and development organisations, media, foundations, charities and religious organisations. Table 2 provides an overview of the governance architecture for the right-to-food.

In summary, concerning the governance structure of the right-to-food and food security, the following conclusions can be made:

$\square$ The governance structure at international level is an UN-based one.

$\square$ Multiple bodies are involved in the food security coordination and monitoring. The creation of the CFS helped to streamline the international effort in this area.

$\square$ International governance of food security suffers from a lack of instruments and methods for effective implementation of the national policies for improving food security in the food-risk countries.

$\square$ Key actors of food security remain at national level. The extent to which individual states adapt their policy due to multinational governance is not evident.

$\square$ Non-state actors are multiple and active in food security. They represent the existing interest of the global civil community in the access to food for every person.

\section{Soft governance innovation: lessons from other policy areas}

The analysis of governance of the right to food and food security revealed its shortcomings in terms: of lack of precision of the commitments; of fragmented governance structures; of monitoring progress; of effective actions pursued by the global community and of ownership.

A parallel can be drawn between governance of the right-to-food and the EU experience of its economic governance in the area where EU Member States are competent for the implementation of economic policies. Due to spill-over effects, the EU has developed an economic governance structure to address this issue. The objective of the bill of comparison is to draw conclusions from the European experience on the subject of the right to food.

In the European Union, two governance methods are used for economic policy coordination. The first one is the "hard" or "normative" governance method based on legal obligations. It is used for the areas where the EU has a competence, for instance: on the correction of budgetary imbalances; on monetary policy or on bank supervision. This hard governance is not relevant for the right-to-food case as EU legislation has not provided for precise obligations to be fulfilled by Member States in this respect.

The second economic governance method of the EU is a "soft" or an "incentive" one. This one is used for policies where Member States are the policy owners or there is a mixed competence between the EU and Member States (Cloos, 2011; Blizkovsky, 2013). The soft governance method has existed since the 1990's when the EU started to be involved in new fields of competencies. An example of this soft governance method was the socalled open method of coordination which was used in the EU's Lisbon Strategy for growth and employment, adopted in 2000. This method aimed at encouraging cooperation, exchanging best practices and agreeing on shared targets supported by national action plans. The Lisbon Strategy was replaced in 2010 by "EU 2020". The governance method is similar to its predecessor but it is more focused, has a smaller number of objectives and has increased the national ownership of the strategy.

As a follow-up to the sovereign debt crisis of the Eurozone as of 2008 the EU's economic governance was broadened and strengthened. In the soft governance, the Euro area Members agreed in 2010 on a pact for the Euro (Stronger Political Policy Coordination for Competitiveness and Convergence) or the "Euro Plus Pact". It contains the commitments of the Euro area Members States to strengthen the economic and social policies in order to not produce negative spill-overs for other Euro area Members.

Another soft economic governance tool in the post-crisis time is the European Semester, adopted in 2010. The main idea of this governance tool is to strengthen the coordination of the shaping of national budgets before national budgets are adopted by national parliaments. The European Semester means that the European Union analyses and evaluates the future budgetary plans of all EU Members in advance. In doing so, the EU takes into account the agreed commitments concerning budgets (stability or convergent programmes) and broader reform plans (national reform programmes). The end product of such coordination is the recommendations issued by the EU

Table 2 Right-to-food governance overview

\begin{tabular}{l|c|c}
\hline Governance level & Bodies (examples) & Responsibility \\
\hline Global & UN, CFS, FAO, WHO, WFP, IFAO, OECD, G8/20 & General guidance, financing \\
\hline Regional & $\mathrm{AU}, \mathrm{ECOWAS,} \mathrm{IGAD,} \mathrm{ECO,} \mathrm{CARICOM,} \mathrm{CAADP}$ & Regional coordination, financing \\
\hline National & States & Implementation \\
\hline Other stakeholders & Civil society, private sector, media, R\&D, foundations & Supporting \\
\hline
\end{tabular}


towards the Member States concerning each budgetary plan. The national parliaments then handle such recommendations; this represents in a way an EU audit of the draft budget, once adopting their national budgets.

The third example of an EU governance tool which can be relevant for the right to food governance comes from the category of normative instruments. After the financial crisis the EU has adopted secondary legislation in order to address macroeconomic imbalances (Zoppé, 2014). This was a farreaching step, taking into account that this is a legally binding mechanism, which can lead to sanctions against the non-complying Member States for policy issues for which Member States are primarily responsible. Therefore, this mechanism substantially strengthens the coordination role of the EU in order to minimise possible negative spill-overs. The mechanism is based on a set of 11 parameters which can lead to possible macroeconomic imbalances. 5 of these mechanisms are linked to external imbalance and competitiveness and cover current account balance, net international investment position, real effective exchange rate, export market shares and unit labour costs. The remaining 6 indicators are related to internal imbalances. They comprise house prices, private sector credit flow, private sector debt, general government debt, unemployment rate and total financial sector liabilities. Each of these 11 indicators has a numeric value both in the parameter itself and in terms of time period under consideration. This governance tool is designed in such a way that the European Commission issues annually "An Alert Mechanism Report" indicating the imbalance risk for individual Member States, followed by in-depth review of macroeconomic imbalances and accompanied by draft Council Recommendations to be addressed by the individual Member States to correct their imbalances. After the Council's Decision, the individual Member States are expected to correct their imbalances within a given timeframe. In the next annual cycle the Commission evaluates whether effective actions have been taken to correct the identified imbalances. In a repetitive noncompliance scenario, the Council can impose financial sanctions on the Member States in question.

The main thrust of the economic governance of the $\mathrm{EU}$ is to ensure that the sovereigns coordinate their economic policies in an effective way while preserving their national ownership. Legal tools as well as soft governance tools are used in this respect.

Looking back at the lessons which the EU case can bring to the governance of right-to-food, the transfer of best practices can arguably be used. The limitation of such a transfer is that the EU is highly integrated regional cooperation based on detailed legal obligations and supported by solid administrative structures, political commitments and judicial framework. This is not the case for the food security issue.

\section{Proposal part}

Nevertheless, the right-to-food has a framework of political commitments which can be used in order to strengthen the implementation of the rightto-food. Four documents represent the core list of guidance, commitments and recommendations. These can create a basis for strengthening governance structure, namely:

$\square$ Global Strategic Framework for food security and nutrition (CFS, 2014). It contains 12 areas which are identified in area of policy, programming and recommendations. They comprise a twin-track between tackling hunger and tackling the roots of hunger, investment in agriculture, food price volatility, gender issues in food security, agriculture productivity, nutrition, tenure of land, fisheries and forests, food security in protracted crisis, social protection, food security and climate change, biofuels and finally, investing in small-holder agriculture. $\square$ Voluntary Guidelines on the Responsible Governance of Tenure of Land, Fisheries and Forests in the Context of National Food Security (CFS (2012). They comprise 26 guidelines in the area of general matters of land tenure, legal aspects, issues related to the right to transfer and duties, guidelines on administration issues such as valuation, taxation, spatial planning or resolution of disputes and topics of climate change, emergency implementations, monitoring and evaluation.

Principles for Responsible Investment in Agriculture and Food Systems (CFS, 2014). They are 10 principles which cover policy to contribute to food security and nutrition, sustainable and inclusive economic development, gender equality, empowering youth, respecting tenure of land, fisheries, forests and access to water, management of natural resources, respecting culture heritage, promoting safe and healthy agriculture, incorporating governance structures and assessing impact and promoting accountability.

Voluntary Guidelines to support the progressive realization of the right to adequate food in the context of national food security (FA0, 2005). They comprise 19 guidelines covering: democracy, good governance, human rights and the rule of law, economic development policies, strategies, market systems, institutions, stakeholders, legal framework, access to resources and assets, food safety and consumer protection, nutrition, education and awareness raising, national financial resources, support for vulnerable groups, safety nets, international food aid, natural and human-made disasters, monitoring, indicators and benchmarks, national human rights institutions and international dimension.

Based on these commitments and taking into account the EU experience, the following governance structure for the right to food can be considered. The CFS could propose to its members an incentive governance structure called Food Security Implementation Procedure (FSIP). It can be guided by the following principles:

Principle 1 - the FSIP would be based on the above 4 documents representing the comprehensive list of global political commitments in the area of food security. They contain 67 items to be monitored, evaluated and pushed for implementation by the global community. This number is obviously too high for sensible governance. Many of the parameters overlap and could therefore be streamlined. Some 10-12 indicators should be part of the procedure. Internal right to food parameters would deal with access to food in the narrow sense and external parameters would deal with structural reforms leading to improvement of right to food.

Principle 2 - the FSIP is a voluntary process, meaning that it is optional for the Member States that are part of the CFS so they can decide whether they wish to be subject of this procedure or not.

Principle 3 - the FSIP would be an evidence-based governance method. The FAO would carry out the policy monitoring and draft independent policy reports.

Principle 4 - the FSIP would work on a measurable set of indicators. The progress in a given Member State and in a given period would be evaluated. For each indicator, a country would be evaluated to see whether a positive, neutral or negative development happened. This evaluation cycle would be tri-annual.

Principle 5 - Member States' ownership would be the basis for any reform efforts and the international community's role would be to facilitate and coordinate such efforts.

Principle 6 - the FSIP would lead to the financial incentives. This principle would mean that the countries which voluntarily agreed to be part 
of the procedure would benefit from financial allocations from international donors, based on their sovereign decision.

Principle 7 - the principle of peer pressure from civil society. As the results of the procedure would be made public the countries making positive progress would profit from positive public opinion for their efforts whilst those who lag behind would be encouraged to improve. The peer pressure incentive for transparency and accountability would have a positive impact on non-participating CFS Members.

Concerning the selection of the indicators, as mentioned under Principle 1, technical and analytical work has already been carried out by the FA0, the IFAD and the WFP (2013). This work covers the internal right to food related parameters and includes a set of 29 indicators. They are split into static and dynamic determinants, covering availability, physical access, economic access, utilisation, vulnerability and shocks (17 indicators) and outcome, such as access and utilization (12 indicators). This represents a solid basis. Concerning the second part, the external factors influence food security in the broader sense and as formulated in the above commitments, e.g. institutional capacity building, ownership rights, investment effort, use of R\&D. This needs to be further developed and taken under political consideration.

The FSIP, as suggested above, would be based on a three year governance cycle within which the Secretariat of the FAO would provide a factual report for each participating member on the implementation of the right to food. The political body of the CFS would endorse such a report and the report would be made public. The international donors would have a powerful instrument at their disposal in order to encourage well-performing countries whilst providing incentives for others. Such governance coordination, at the international level, would strengthen the national ownership of the right to food policy which is the key governance level of the whole concept. Finally, the non-public sector represented by civil society, private foundations, media, research centres and others would have at their disposal an objective instrument for adjusting their activities.

\section{Conclusions}

The right to food and food security belongs to the key global political priorities even though in the last decades a considerable improvement has happened, there are still a non-tolerable number of individuals suffering from hunger and malnutrition.

The concept of right-to-food is based on two pillars: legal and political. The legal part benefits from the universal recognition of the right which in turn belongs to the list of universally recognised human rights. On the weak side, this concept lacks any binding nature and direct applicability. These depend on the transposition of the right-to-food into national constitutions and national legal systems. In practice the right-to-food is likely to be enforceable in a growing number of countries but still only in a minority of countries at this stage.

The political part of the right-to food concept is marked by multiple commitments made at the Heads of States and Ministerial levels on multiple occasions. On the weak side such commitments are overlapping, lacking in measureable elements, clear timelines and enforceability.

The article draws a parallel between the recent evolution in the European Union after its 2008 sovereign debt crisis and a consequent strengthening of the EU's economic governance. The incentive part of the soft governance of the EU can serve as a model for the right-to-food governance. It is proposed to set up a Food Security Implementation Procedure. This would be a voluntary governance mechanism open to CFS Members. The FAO would serve as secretarial support to it in order to establish an independent and factual evaluation of the progress made by Member States within the given set of indicators. Around a dozen indicators, both linked to the narrow concept of right-to-food and of a broader structural nature, would be evaluated every three years. Once endorsed on the political level by the CFS, such a report would provide incentives for international donors to allocate financial resources effectively to the countries manifesting willingness to improve the food security. The mechanism would also increase the ownership of food security at national level via transparency, evaluation and lessons learnt. Finally, the procedure would be beneficial for the third governance level, the non-public one. Both civil society and the private sector would dispose of authority over governance improvement or lack of it around the world.

The right-to-food is arguably high on the list of collective actions in today's world. The global community is lacking stream-lined governance to encourage national actors effectively. By addressing this governance issue the international community could provide a better service to today's world.

\section{References}

ACORD. 2010. Global food governance, The Committee for World Food Security, Policy Briefing Paper 10, ACK Garden House, Kenya.

BLIZKOVSKY, P. 2013. Economic governance: What can the EU and ASEAN learn from each other after the economic crisis? In Journal of Southeast Asian Economics, vol. 30, 2013, no. 1, pp. 1-18.

CFS. 2012. Voluntary Guidelines on the Responsible Governance of Tenure of Land, Fisheries and Forests in the Context of National Food Security. FA0, Rome, 9 March 2012. Available at: www.cfs.org

CFS. 2014. Principles for Responsible Investment in Agriculture and Food Systems. Available at: www.cfs.org

CLOOS, J. 2011. "Incentive" governance: a key component of a future European economic governance. In Lepoivre, M. - Keller-Noellet, J. - Verhelst, S. (eds). The European Union and Economic Governance. Studia Diplomatica, Ghent : Academia Press.

COURTIS, Ch. 2007. The Right to Food as a Justiciable Right: Challenges and Strategies. In Max Planck Yearbook of UN Law, vol. 11, 2007, pp. 317-337.

De HAEN, H. - MacMILLAN, A. 2010. Towards global governance of food security. In Rural 21 Focus, 2010, no. 5.

De SCHUTTER, 0. 2008. Promotion et protection de tous les droits de I'homme, civils, politiques, économiques, sociaux et culturels, y compris le droit au développement. In United Nations General Assembly A/HRC/9/23, 43 p.

De SCHUTTER, 0. 2009. Promotion and protection of all human rights, civil, political, economic, social and cultural rights, including the right to development, Human Rights Council, Tenth session, Agenda item 3, A/HRC/10/5, 11 February 2009.

De SCHUTTER, 0. 2010. The right to food, Catholic Social Doctrine and Human Rights. Pontifical Academy of Social Sciences, Acta 15, Vatican City 2010.

FA0. 2005. Voluntary Guidelines to Support the Progressive Realisation of the Right to Adequate Food in the Context of National Food Security. ISBN 92-5-105336-7.

FA0. 2014a. The Zero Hunger Challenge: Can we create a world where no one is hungry? http://www.fao.org/zhc/details/en/246110

FA0. 2014b. Global and regional FSN governance http://www.fao.org/righttofood/ourwork/global-and-regional-fsn-governance/en/

FA0. 2014c. Improved Global Governance for Hunger Reduction Programme. http://www. fao.org/righttofood/our-work/current-projects/improved-global-governance-forhunger-reduction/governance/en/

FA0. 2014d. Africa Solidarity Trust Fund by Africans for Africans. A unique, Africa-led fund to improve agriculture and food security across the continent has become a reality, http://www.fao.org/assets/infographics/FA0-Infographic-ASTF-en.pdf

FA0. 2015. Understanding hunger and malnutrition. Report, available on: www.fao.org/ icn2

FAO and WH0. 2014a. Second International Conference on Nutrition. In Conference Outcome Document: Rome Declaration on Nutrition, ICN2 2014/2, Rome, 19-21 November 2014. http://www.fao.org/3/a-ml542e.pdf

FAO and WHO. 2014b. Second International Conference on Nutrition. In Conference Outcome Document: Framework for Action, ICN2 2014/3 Corr. 1, Rome, 19-21 November 2014. http://www.fao.org/3/a-mm215e.pdf 
FAO and WHO. 2014c. Second International Conference on Nutrition. Roundtable 3: Governance and Accountability for Nutrition, ICN2 2014/RT/3, Rome, 19-21 November 2014. http://www.fa0.org/3/a-ml933e.pdf

FA0, IFAD and WFP. 2013. The State of Food Insecurity in the World 2013. In The multiple dimensions of food security. Rome : FA0. ISBN 978-92-5-107916-4.

GOLAY, Ch. 2008. La crise alimentaire mondiale et le droit à l'alimentation, CETIM, Cahier critique, no 3, Série: Droit à l'alimentation, Genève, $16 \mathrm{p}$.

GOLAY, Ch. 2010. The Food Crisis and Food Security: Towards a New World Food Order? Dossier Africa: 50 years independence - Review, The Graduate Institute, Geneva. pp. 215-232.

GOLAY, CH. - ÖZDEN, M. 2012. Le droit à l'alimentation. Un droit humain fondamental stipulé de I'ONU et reconnu par des traités régionaux et de nombreuses constitutions nationales, Une collection du Programme Droit Humains du Centre Europe - Tiers Monde (CETIM), $56 \mathrm{p}$.

HIGH LEVEL PANEL of Experts on Food Security and Nutrition. 2014a. Food losses and waste in the context of sustainable food systems, HLPE Report 8, 13901E/1/06.14. http://www.iufost.org/iufostftp/FLW-\%20FA0.pdf

HIGH LEVEL PANEL of Experts on Food Security and Nutrition (2014b): Extract from the Report. Biofuels and Food Security, HLPE REV 3. http://www.fao.org/fileadmin/user_ upload/hlpe/hlpe_documents/HLPE_S_and_R/HLPE_2013_Biofuels_Summary_ EN.pdf

HUMAN RIGHTS COUNCIL. 2010. Report submitted by the Special Rapporteur on the right to food, Olivier De Schutter, Sixteenth session, Agenda item 3, A/HRC/16/49, 20 December 2010.

LANRE, A. 2015. A review of the three generations of human rights. http:// thelawyerschronicle.com/a-review-of-the-three-generations-of-human-rights/, consulted on 20 January 2015

McKEON, N. 2011. Global Governance for World Food Security: A Scorecard Four Years After the Eruption of the "Food Crisis". Berlin : Heinrich BöllStiftung, 2011.
MECHLEM, K. 2004. Food Security and the Right to Food in the Discourse of the United Nations. In European Law Journal, vol. 10, 2004, no. 5, pp. 631-648.

MICHAEL, J. - McDermott. 2012. Constitutionalizing an Enforceable Right to Food: A Tool for Combating Hunger. 35 B.C. Int'I \& Comp. L. Rev. 543. 2012. http:// lawdigitalcommons.bc.edu/idr/vol35/iss2/7

PAARLBERG, R. L. 2002. Governance and Food Security in an Age of Globalization, Food, Agriculture, and the Environment Discussion Paper 36, International Food Policy Research Institute. ISBN 0-89629-642-3.

PAGE, H. 2013. Global Governance and Food Security as Global Public Good. New York : Centre on International Cooperation, 2013.

PISANELLO, D. 2009. What do Food Safety and Fair Trade Stand for? Reconciling the Twofold Objective of EU Food Law. In European Food and Feed Law Review, vol. 4, 2009, no. 5, pp. 320-328.

RICHES, G. - SILVASTI, T. 2014. First World Hunger Revisited. Food Charity or the Right to Food? $2^{\text {nd }}$ ed., Palgrave Macmillan, 2014. ISBN 978-1-137-29872-0.

ZIEGLER, J. - GOLAY, CH. - MAHON, C. - WAY, S. 2011. The fight for the right to food Lessons learned. Geneva : The Graduate Institute, Palgrave Macmillan. ISBN 978-0230-28464-7.

ZOPPÉ, A. 2014. Implementation of the macroeconomic imbalance procedure. Briefing, European Parliament, 2014. PE 497-739, Brussels.

\section{Contact address}

Petr Blizkovsky, General Secretariat of the Council of the European Union 